\title{
TECHNIKI ROZWIJANIA SPRAWNOŚCI SŁUCHANIA I MÓWIENIA W PODRĘCZNIKACH DO NAUCZANIA POLSKIEGO JEZZYKA MEDYCZNEGO
}

\begin{abstract}
Słowa kluczowe: język specjalistyczny, polski język medyczny, materiały dydaktyczne, sprawności językowe, techniki rozwijające sprawność słuchania i mówienia

Streszczenie. Artykuł stanowi głos w dyskusji nad sposobami rozwijania sprawności słuchania oraz mówienia w nauczaniu polskiego języka medycznego. Przyczynkiem do napisania tekstu były konkluzje płynące $\mathrm{z}$ analizy koncepcji rozwijania sprawności językowych przedstawionych we wstępach do podręczników do nauki (polskiego) języka medycznego. W pierwszej części przedstawione zostały dotychczasowe prace na temat podręczników i pomocy do nauczania polskiego języka medycznego. W drugiej części opisano techniki rozwijania sprawności słuchania i mówienia powszechnie przyjęte w metodyce nauczania polskiego języka ogólnego oraz do celów specjalistycznych. Następnie dokonano weryfikacji mieszczących się we wstępach do podręczników deklaracji oraz koncepcji autorów poprzez ich zestawienie ze stanem rzeczywistym materiałów zawartych w książkach. Autorka omówiła również techniki nabywania oraz rozwijania umiejętności słuchania i mówienia w podręcznikach do języka medycznego.
\end{abstract}

\section{WPROWADZENIE}

Nauczanie języka polskiego dla potrzeb zawodowych i specjalistycznych nie jest zjawiskiem nowym, choć nie da się ukryć, że postępująca globalizacja, którą przyniosły minione dwie dekady XXI, wymusiła większe zainteresowanie glottodydaktyków kształceniem specjalistycznym Wzrost znaczenia polskich uczelni na rynku edukacji międzynarodowej dał początek m.in. programom medycznym w języku angielskim, a ośrodki akademickie stanęły przed wyzwaniem tworzenia kursów oraz lektoratów skoncentrowanych na nauczaniu polskiego języka medycznego wśród cudzoziemców. Ponadto lekarz obcokrajowiec, który zamierza

* oczkopana@gmail.com, Katolicki Uniwersytet Lubelski Jana Pawła II, Wydział Nauk Humanistycznych, Katedra Języka Polskiego, Al. Racławickie 14, 20-950 Lublin. 
podjąć pracę w swoim zawodzie w Polsce, jest zobligowany do potwierdzenia swojej znajomości polszczyzny ${ }^{1}$. Wobec tego zarówno przed praktykami, jak i teoretykami pojawiają się kolejne wyzwania z zakresu glottodydaktyki polonistycznej do celów specjalistycznych.

Nauczanie polskiego języka medycznego ma na celu przygotowanie studentów do efektywnego funkcjonowania zawodowego w środowisku polskojęzycznym (co jest istotne dla perspektywy badawczej przyjętej w niniejszym artykule). Nadrzędnym celem kształcenia w tym zakresie jest doskonalenie kompetencji komunikacyjnej oraz skupienie się na zagadnieniach językowych ściśle wynikających $\mathrm{z}$ funkcjonowania zawodowego $\mathrm{w}$ środowisku medycznym, w tym pogłębianiu znajomości terminologii medycznej i leksyki z zakresu nauk medycznych

\subsection{PROBLEM I CEL BADAWCZY}

Celem niniejszego artykułu jest weryfikacja zawartych we wstępach do podręczników deklaracji oraz koncepcji autorów pod kątem technik rozwijania sprawności słuchania oraz mówienia ze stanem rzeczywistym materiałów zawartych w tych materiałach.

Dokonane na potrzeby innego opracowania analizy koncepcji metodycznych twórców wydanych do tej pory podręczników do nauczania polskiego języka medycznego wykazały, że w zdecydowanej większości analizowanych koncepcji metodycznych dominuje przekonanie, iż rozwijanie sprawności słuchania i mówienia - rozwijanie kompetencji komunikacyjnej - jest najbardziej pożądane i wymagane w procesie nauki omawianego tu języka specjalistycznego ${ }^{2}$. Spośród czterech sprawności językowych najrzadziej uwzględnianą w deklaracjach autorów podręczników jest sprawność pisania (tendencja ta utrzymuje się we wstępach do wszystkich badanych publikacji). Drugą umiejętnością postrzeganą za najmniej potrzebną przyszłym medykom jest rozumienie tekstu pisanego.

Autorzy najnowszej publikacji zatytułowanej U lekarza zwracają uwagę na konieczność nabycia przez uczących się kompetencji rozumienia ze słuchu. W przedstawionej koncepcji podręcznika wyraźnie deklarowane jest również rozwijanie innych sprawności: mówienia oraz czytania ze zrozumieniem, por.:

Do tej pory na rynku księgarskim brakowało pozycji, która umożliwiałaby skuteczne nauczanie języka polskiego medycznego na poziomach podstawowym i średnim. U lekarza tę lukę wypełnia, oferując bogaty materiał ćwiczeniowy pozwalający na doskonalenie tekstu pisanego oraz rozwijanie sprawności mówienia, a przede wszystkim, co szczególnie

${ }^{1}$ Cudzoziemcy są zobowiązani zdać egzamin z języka polskiego, za którego organizację odpowiada Naczelna Rada Lekarska. Zob. https://nil.org.pl/dla-lekarzy/mlodzi-lekarze/4282-egzaminyz-jezyka-polskiego [04.06.2020].

${ }^{2}$ Por. Oczko, w druku. 
warte podkreślenia, najwięcej uwagi poświęca się rozumieniu ze słuchu. [...] Opracowanie kładzie szczególny nacisk na kształcenie sprawności rozumienia ze słuchu, poświęca jednak także sporo uwagi słownictwu, rozumieniu tekstu pisanego i komunikacji.

(Rogala i in. 2019, s. 7)

Sprawność komunikacyjna z góry zakłada ciąg następujących po sobie i wynikających z siebie interakcji stucham - rozumiem/nie rozumiem - reaguję: odpowiadam/pytam. Dlatego można przyjąć, że w podręcznikach, które w zamyśle autorów są nastawione na nabywanie i rozwijanie kompetencji komunikacyjnych, będzie również w szczególny sposób akcentowana rola sprawności słuchania i mówienia. Spośród takich pozycji należy przywołać Proszę mi powiedzieć, co się stało? Podręcznik języka polskiego dla studentów medycyny T. Jurka (2007), Chcę studiować medycynę. Język polski dla cudzoziemców - kandydatów na studia medyczne J. Lechowicz i J. Podsiadły (1997), Co Panu dolega? Podręcznik z płyta CD do nauczania cudzoziemców języka polskiego na studiach medycznych. Poziom B2/C, M.Chłopickiej-Wielgos, D. Pukas-Palimąki i K. Turek-Fornelskiej (2015) oraz Witaj w Polsce. Podręcznik do nauki języka polskiego dla studentów B. Bilnickiej (2018).

Przedstawione wyżej spostrzeżenia i konkluzje stały się przyczynkiem do szerszych rozważań na temat obecnego stanu badań nad opisem sprawności receptywnych i produktywnych dla celów specjalistycznych. Rewizja deklaracji oraz koncepcji autorów ze stanem faktycznym materiałów zawartych w podręcznikach pozwoli na dokładny opis metod i technik nabywania oraz rozwijania umiejętności słuchania i mówienia (a później czytania i pisania), jak również na określenie faktycznego miejsca sprawności receptywnych i produktywnych w procesie nauczania polskiego języka medycznego ${ }^{3}$.

\subsection{Z BADAŃ NAD MATERIAŁAMI DO NAUCZANIA POLSKIEGO JĘZYKA MEDYCZNEGO}

Podręczniki do nauki języka medycznego nie były dotychczas przedmiotem zainteresowania szerokiego grona badaczy języków specjalistycznych, niemniej jednak powstały już pewne opracowania na ten temat, które warto tu przywołać.

\footnotetext{
${ }^{3}$ Ze względu na trudności w dostępie do niektórych materiałów oraz ograniczenia tekstowe artykułu, w niniejszej analizie pominięto następujące pozycje: M. Ławnicka-Borońska (2013) - zgodnie z zamiarem autorki stanowi kompendium (leksykon) polskiego słownictwa medycznego; K. Sokołowska i in. (2003) - jest przeznaczony jest do nauki języka ogólnego na poziomie A1/A2; E. Gałat (2018) - autorka podkreśla, iż podręcznik jest przeznaczony do pracy na zajęciach ze słownictwa specjalistycznego. Zarówno podręcznik A. Daneckiej-Chwals, M. Chłopickiej, D. Pukas-Palimąki (1986), jak i M. Janowskiej, Ś. Sikorskiej (2007b, 2015) - w czasie przygotowywania artykułu były trudne do pozyskania.
} 
Jedne z pierwszych artykułów zarówno podejmujących zagadnienie nauczania polskiego języka medycznego, jak i sugerujących pewne założenia teoretyczne i rozwiązania metodologiczne to $Z$ zagadnień nauczania odmiany specjalistycznej języków obcych (na przykładzie nauczania języka medycznego studentów polonijnych) z 1979 roku, a także Założenia metodyczne i lingwistyczne podręcznika języka medycznego dla studentów polonijnych z 1981 r. autorstwa Alicji Daneckiej-Chwals, Danuty Pukas-Palimąki i Marii Chłopickiej. W 1988 r. Chłopicka i Pukas-Palimąka opublikowały tekst Zatożenia lingwistyczne $i$ metodyczne drugiej części podręcznika języka medycznego dla studentów polonijnych, który omawiał zawartość podręcznika Co panu dolega? oraz jego założenia metodyczne oparte na metodzie komunikacyjnej. Autorki podkreśliły również rangę funkcji językowych służących do nawiązywania i podtrzymywania kontaktu językowego. W 1996 r. te same autorki w pracy zatytułowanej Nauczanie języka specjalistycznego a nie tylko terminologii dokonały charakterystyki stylu naukowego oraz przeglądu literatury dotyczącej tego zagadnienia. Dodatkowo zwróciły uwagę, iż nie istnieje specjalna metodyka nauczania języka specjalistycznego.

Katarzyna Taczyńska w artykule z 2011 r. zatytułowanym Językowe dolegliwości lekarzy obcokrajowców poddała analizie pięć podręczników ${ }^{4}$ pod względem ich użyteczności jako materiałów przygotowujących do egzaminu z języka polskiego organizowanego przez Naczelną Radę Lekarską. Autorka przedstawiła formę egzaminu i podkreśliła, że w trakcie jego przebiegu testowane są cztery sprawności - mówienie, rozumienie tekstu pisanego, rozumienie ze słuchu oraz pisanie, ale swoją analizę skupiła na szczegółowej weryfikacji podręczników pod kątem terminologii medycznej, a zagadnienia dotyczące sprawności językowych ograniczyła do pojedynczych uwag. Magdalena Ławicka-Borońska, Weronika Janina Rudnik oraz Justyna Wiśniewska w pracy Kurs języka polskiego jako obcego dla studentów medycyny poświęciły uwagę trzem pozycjom $^{5}$. Wprawdzie w ujęciu całościowym podręczniki spotkały się z przychylną oceną autorek artykułu, nie zabrakło jednak słów krytyki. Za dwie największe wady uznano odejście od metody gramatyczno-tłumaczeniowej w prezentacji materiału leksykalnego i gramatycznego oraz brak materiałów audiowizualnych. Z kolei w 2016 r. ukazał się artykuł Magdaleny Ławnickiej-Brońskiej oraz Kamili Kubickiej pt. Język polski medyczny w wybranych materiatach dydaktycznych ostatniego ćwierćwiecza. Autorki dokonały przeglądu 23 książek do nauki języka ogólnego na poziomie A1-A2 i 7 podręczników, skryptów i pomocy dydaktycznych z zakresu języka polskiego specjalistycznego ${ }^{6}$. Weryfikacja materiałów

${ }^{4} \mathrm{~W}$ artykule omówione zostały następujące podręczniki: A. Daneckia-Chwals, M. Chłopicka, D. Pukas-Palimąka (1986), M. Chłopicka, D. Pukas-Palimąka, K.Turek-Fornelska (2015), J. Lechowicz, J. Podsiadły (1998), Ś. Sikorska i M. Janowska (2007b) oraz T. Jurek (2007).

${ }^{5}$ Te pozycje to: T. Jurek (2007), Ś. Sikorska i M. Janowska (2007) oraz B. Bilnicka (2003).

${ }^{6}$ Analizie zostały poddane następujące książki: B. Bilnicka (2018), M. Janowska, Ś. Sikorska (2007a, 2007b, 2015), T. Jurek (2007) oraz M. Ławnickia-Borońska (2013). 
dydaktycznych pokazała niewystarczającą obecność zagadnień z zakresu szeroko pojętego zdrowia i medycyny w materiałach ogólnych oraz deficyt pozycji do nauczania języka medycznego.

Wzmianka na temat materiałów dydaktycznych do nauki języka polskiego specjalistycznego z dziedziny medycyny i stomatologii (łącznie dziesięć pozycji) ${ }^{7}$ pojawia się w pracy Czy możliwe jest zanurzenie w języku specjalistycznym z 2018 r. Urszuli Swobody-Rydz. Wprawdzie autorka nie dokonuje analizy wymienianych w swoim tekście materiałów, niemniej jednak stawia tezę, iż prawdziwie komunikacyjne zadania językowe nie są możliwe do wprowadzenia na poziomie A2 - jest to realne dopiero na wysokim szczeblu zaawansowania językowego, czyli B2/C1.

\section{SPRAWNOŚĆ SŁUCHANIA I MÓWIENIA - ZAŁOŻENIA TEORETYCZNE W NAUCZANIU POLSKIEGO JEZZYKA OGÓLNEGO ORAZ DO CELÓW SPECJALISTYCZNYCH}

W nowoczesnej dydaktyce nauczania języków obcych stawia się pytanie o zasadność izolowania sprawności, a ich rozgraniczenie często określane jest jako zabieg sztuczny, w komunikacji bowiem sprawności te nigdy nie są wykorzystywane oddzielnie (Chłopek 2016, s. 4). Takie wyodrębnianie sprawności często jednak znajduje uzasadnienie, przykładowo w pracy ze studentem o określonych dysfunkcjach albo potrzebach językowych ${ }^{8}$.

Wbrew powszechnej opinii nauka języka dla potrzeb zawodowych nie powinna koncentrować się wyłącznie na fachowej leksyce (Zawadzka 2004, s. 140). Zarówno w nauczaniu języka ogólnego, jak i do celów zawodowych główny akcent kładzie się na osiągnięciu umiejętności naturalnego i skutecznego porozumiewania się w obrębie czterech sprawności językowych.

Rozumienie ze słuchu jest nieodłącznym elementem życia codziennego. Słuchanie to nie tylko niezależna i samodzielna sprawność językowa, ale również niezastąpiona część składowa komunikacyjnej umiejętności językowej. Rozwi-

${ }^{7}$ Z pozycji niewymienionych do tej pory: U. Swoboda-Rydz (2016) oraz K. Sokołowska, T. Jurek, K. Labuda-Di Mario, B. Tuczyńskia-Nowak (2009). Druga pozycja nie stanowi materiału do nauczania języka specjalistycznego, choć jest kierowana do dość jasno sprecyzowanej grupy odbiorców. Autorzy podkreślają: „Podręcznik został napisany z myślą o studentach Uniwersytetu Medycznego w Poznaniu, dla których językiem wykładowym jest język angielski. Podręcznik przeznaczony jest do nauki języka ogólnego na poziomie podstawowym (A1/A2) pod kierunkiem lektora i przewidziany jest na ok. 150 godzin" (Sokołowska i in. 2003, s. 5).

${ }^{8} \mathrm{Z}$ uwagi na ograniczenia objętościowe artykułu analizy formułowano jedynie $\mathrm{w}$ odniesieniu do tradycyjnego postrzegania sprawności. Dalsze badania uwzględnią współczesną wizję sprawności językowych wyrażoną w ESOKJ. 
janie sprawności słuchania prowadzi do nauczania elementów języka (wyrazów, zwrotów, struktur), wykonania określonego zadania, osiągnięcia zamierzonego celu oraz płynnego przejścia do innych sprawności. Gabriela Filipowicz zwraca uwagę, iż słuchanie nie należy do często badanych obszarów (Filipowicz 2016, s. 61). Choć wydaje się, że owa opinia jest nieco przesadzona, nie sposób się z nią nie zgodzić 9 . Podsumowując dorobek glottodydaktyki polonistycznej, Władysław Miodunka stwierdził:

Jak wyraźnie pokazały to autorki $A B C$ metodyki, problematykę nową w nauczaniu JPJO stanowi nauczanie sprawności językowych. Autorów prac na ten temat nie ma wielu, co zapewne wynika z faktu, że każdy zajmujący się sprawnościami językowymi musi wykroczyć daleko poza tradycyjne granice badań prowadzonych przez językoznawstwo polonistyczne. [...] Praca Rozwijanie sprawności rozumienia ze stuchu w języku polskim jako obcym Adriany Prizel-Kani jest tylko zwiastunem nowego kierunku prac, które powinny być kontynuowane.

(Miodunka 2016, s. 77, 338)

Oprócz publikacji Adriany Prizel-Kani warto wspomnieć o tekście Anny Burzyńskiej-Kamienieckiej (2015) pt. Umiejętność rozumienia ze stuchu w świetle Europejskiego systemu opisu kształcenia językowego i Standardów wymagań egzaminacyjnych oraz artykule Małgorzaty Gaszyńskiej-Magiery (2008) zatytułowanym Stuchanie - sprawność trudna, zaniedbywana, czy źle uczona? Niemniej jednak najbardziej znanym i najczęściej przywoływanym podręcznikiem, w którym szeroko omówione zostały techniki wspomagające rozwijanie sprawności słuchania, jest Metodyka nauczania języków obcych Hanny Komorowskiej. Autorka dokonała podziału na techniki poprzedzające słuchanie, towarzyszące słuchaniu, następujące po wysłuchaniu tekstu oraz techniki, za pomocą których można łączyć tę sprawność z innymi, następnie zaprezentowała liczne przykłady ćwiczeń, które można wykorzystać w każdej fazie (Komorowska 2009, s. 174-186).

Wydaje się, że sprawność mówienia jest najbardziej pożądaną umiejętnością w nauczaniu języka obcego ${ }^{10}$. „Dziś, gdy kontakty bezpośrednie stały się znacznie ułatwione wskutek rozwoju transportu i telekomunikacji, rola sprawności mówienia ogromnie wzrosła. Dlatego umiejętność swobodnego wypowiadania się jest dla wielu osób miarą sukcesu w nauce języka" (Komorowska 2009, s. 196). Od lat zagadnienie efektywnego uczenia komunikacji jest przedmiotem

\footnotetext{
${ }^{9} \mathrm{Na}$ stronie internetowej Szkoły Języka i Kultury Polskiej Uniwersytetu Śląskiego w zakładce Biblioteka lektora znajduje się wykaz materiałów pomocniczych przeznaczonych do rozwijania konkretnych kompetencji (pod uwagę nie są brane podręczniki kursowe). Na uwagę zasługuje liczba podręczników przypisanych do każdej ze sprawności: czytanie - 10 pozycji, pisanie - 8, mówienie oraz słuchanie - 3. Zob. http://www.sjikp.us.edu.pl/pl/biblioteka-lektora/materialy-pomocniczerozne-kompetencje/ [04.06.2020].

${ }^{10}$ Rozwijaniu sprawności mówienia nieodłącznie towarzyszy uczenie poprawnej wymowy: rozpoznawanie i produkcja dźwięków, nauczanie akcentu wyrazowego i zdaniowego oraz intonacji.
} 
badań i dyskusji zarówno w polskich, jak i anglosaskich opracowaniach (Janowska 2019, s. 130-135). Zaproponowana przez Hannę Komorowską typologia technik opartych na bodźcu wizualnym, słownym i dźwiękowym, które wspomagają rozwijanie sprawności mówienia, została wykorzystana w opracowaniach takich jak: ABC metodyki nauczania języka polskiego jako obcego Anny Seretny i Ewy Lipińskiej z 2005 r. oraz Techniki nauczania języka obcego z 2011 r. autorstwa Elżbiety Gajewskiej. Cennym głosem w sprawie rozwijania sprawności mówienia jest również opublikowana w 2019 roku książka Iwony Janowskiej Wypowiedź ustna $w$ dydaktyce językowej. Na przyktadzie języka polskiego jako obcego.

Sposobom konstruowania ćwiczeń wspomagających rozwijanie rozumienia ze słuchu w uczeniu (się) języka specjalistycznego nie poświęcono zbyt wiele badań, dlatego też instrukcje metadydaktyczne bazują przede wszystkim na metodach nauczania języka ogólnego (Gajewska, Sowa 2014, s. 176).

Najważniejszą funkcją, jaką ma spełnić akt mówienia, jest wypełnienie luki informacyjnej, dlatego wypowiedzi ustne muszą być informacyjnie skuteczne, stosowane formalnie i społecznie (Gajewska, Sowa 2014, s. 180). Zadaniem nauczyciela języka specjalistycznego jest pomoc w opanowaniu wymienionych strategii tak, aby uczący się wypracowali nawyk monitorowania efektywności wypowiedzi, dokonywania autokorekty, a w razie konieczności sięgania po różne strategie. Przygotowanie do wypowiedzi ustnej powinno przebiegać według planu, który obejmuje następujące etapy: zapoznanie się z nowym słownictwem i strukturami składniowymi, przećwiczenie nowo poznanej leksyki w ćwiczeniach, stworzenie wypowiedzi ustnej. Gradacja ćwiczeń pozwala na płynne przejście od wypowiedzi silnie strukturyzowanych do wypowiedzi swobodnej. Poznanie leksyki w różnym kontekście przekłada się na kreatywność oraz naturalność późniejszych, swobodnych wypowiedzi. Reasumując, ćwiczenia rozwijające sprawność mówienia do celów zawodowych bazują na kanwie zadań w nauczaniu języka ogólnego ${ }^{11}$. Przemysław Gębal w swojej publikacji podsumowuje: „Zmieniające się podejście w zakresie ogólnej dydaktyki językowej każdorazowo wpływało także na sposób realizacji zajęć z zakresu języków dla potrzeb zawodowych i specjalistycznych. Stąd w obszarze nauczania języków do tego typu celów znajdujemy koncepcje dydaktyczne zorientowane behawioralnie, kognitywnie i konstruktywistycznie" (Gębal 2019, s. 280).

${ }^{11}$ Wśród nich można wyliczyć: dubbingowanie nagrań wideo, uzupełnianie brakujących replik w nagranym dialogu, ogrywanie ról zgodnie z wytycznymi, ćwiczenia symulacyjne, tworzenie wypowiedzi według wytycznych, odpowiadanie na pytania, wnioskowanie na podstawie materiałów pomocniczych (obrazek, przedmiot, dźwięk, nagranie wideo), tworzenie konkretnych typów wypowiedzi ustnej: monolog, prezentacja, mowa argumentacyjna (Gajewska, Sowa 2014, s.182). 


\subsection{ANALIZA MATERIAŁU}

Analiza badanego materiału miała przebieg dwuetapowy. Pierwszy etap polegał na zestawieniu deklaracji oraz koncepcji autorów dotyczących technik rozwijania sprawności słuchania oraz mówienia zawartych w podręcznikach. Kolejnym krokiem - w odniesieniu do książek, które nie tylko deklarują rozwijanie sprawności słuchania i mówienia, ale faktycznie zawierają materiały temu służące - była ocena wykorzystanych technik na podstawie samodzielnie przeze mnie sformułowanych kryteriów. W odniesieniu do sprawności słuchania były to:

- ocena technik wykorzystywanych we wstępnej fazie (przed słuchaniem) - o ile zostały uwzględnione w podręczniku,

- techniki towarzyszące słuchaniu,

- techniki następujące po wysłuchaniu tekstu.

Natomiast w przypadku technik wspomagających rozwijanie sprawności mówienia ocenione zostały:

- materiały stymulujące wypowiedzi,

- techniki utrwalające nowo poznaną leksykę,

- techniki wspomagające tworzenie samodzielnej wypowiedzi.

Pod uwagę brano również stopień trudności ćwiczeń oraz jakość materiałów audio.

1. Chcę studiować medycynę. Język polski dla cudzoziemców - kandydatów na studia medyczne

Podręcznik, choć po raz pierwszy został wydany pod koniec lat 90. XX w., a później jego publikacja była wznawiana, nie posiada nośnika z nagraniami audio ani ćwiczeń rozwijających sprawność słuchania.

Charakterystyczne dla książki jest umieszczanie na wstępie każdej jednostki lekcyjnej pytania wprowadzającego w tematykę. Dzięki bodźcowi słownemu osoba ucząca się już na samym początku jest wprowadzana w treść omawianego zagadnienia. Inwentarz pytań jest bardzo zróżnicowany i pytania nie do końca są stricte specjalistyczne ${ }^{12}$. Poruszają zagadnienia związane $\mathrm{z}$ medycyną, ale w sposób ogólny. Najczęściej wykorzystywaną techniką wspomagającą rozwijanie sprawność mówienia jest odgrywanie ról. Postaci, w które musi wcielić się student, to: lekarz organizujący rozmowę kwalifikacyjną z kandydatami na lekarza w szpitalu; lekarz, który udziela pomocy osobie ze złamaną albo zwichniętą

${ }^{12}$ Wybrane pytania wprowadzające: Jakim specjalista chcialbyś zostać i dlaczego?; Jaka powinna być pielegniarka? Czy wystarczy, żeby pielegniarka była ładna?; Czym zajmuje się medycyna?; Jakie zna Pan/Pani witaminy? Gdzie występuja witaminy, jakie choroby wywoluje niedobór witamin?; Co Pan wie o AIDS?; Czy w Pani/Pani kraju ludzie często pija alkohol, kawę, herbatę i pala papierosy? 
nogą, skaleczeniem, oparzeniem, krwotokiem z nosa ${ }^{13}$. W podręczniku dominują ćwiczenia skupiające się na umiejętnym tworzeniu wypowiedzi monologowych oraz na uzasadnianiu swojej opinii ${ }^{14}$.

2. Proszę mi powiedzieć, co się stało? Podręcznik języka polskiego dla studentów medycyny

W omawianym podręczniku brakuje ćwiczeń, które byłyby nastawione na rozwijanie sprawności słuchania. Jest to o tyle dziwne, iż autor we wstępie pisze m.in.:

Celem książki jest wprowadzenie terminologii medycznej i wykorzystania jej w rozmowach z pacjentami w czasie praktyk lekarskich. [...] Ćwiczenia mają utrwalić umiejętność prowadzenia dialogu z pacjentem. [...] Praca z podręcznikiem pozwala studentom usystematyzować i utrwalić terminologię medyczną i występować w roli lekarza.

(Jurek 2007, s.6)

Wysunięcie na pierwszy plan sprawności komunikacyjnej wymaga wręcz rozwijania umiejętności słuchania ze zrozumieniem oraz mówienia. Pozostaje zadać pytanie: jak można komunikować się bez umiejętności słuchania? W intencji autora podręcznik miał stanowić pomoc w opanowaniu terminologii medycznej i uczyć, jak sprawnie wykorzystać leksykę specjalistyczną w rozmowie z pacjentami w czasie praktyk, a ćwiczenia były nastawione przede wszystkim na nabywanie i doskonalenie umiejętności komunikacyjnych. Niestety, mimo takiego założenia, techniki rozwijania sprawności mówienia prezentują się bardzo ubogo. Wprawdzie podręcznik daje potrzebne narzędzie - prezentuje krótkie dialogi lekarz - pacjent, dodatkowo najpotrzebniejsze słownictwo jest zebrane w przejrzyste tabele zatytułowane: Przydatne pytania $i$ zwroty. Zwraca jednak uwagę brak technik rozwijających kreatywność, które posłużyłyby do tworzenia własnych wypowiedzi. Analiza materiału wykazała, iż sprawność mówienia - mimo zamysłu autora - nie jest w podręczniku rozwijana.

3. Co panu dolega? Podręcznik do nauczania języka polskiego medycznego na poziomie $\mathrm{B} 2 / \mathrm{Cl}$

W tej publikacji sprawność słuchania jest kompetencją, na którą kładzie się duży nacisk od pierwszych jednostek lekcyjnych. Zadania towarzyszące słuchaniu to uzupełnianie brakujących słów w tekście (czasami wyrazy są podane w ta-

${ }^{13} \mathrm{~W}$ podręczniku pojawiły się jeszcze trzy podobne ćwiczenia. W pierwszym z nich osoba ucząca się ma za zadanie wcielić się w rolę egzaminatora pytającego studenta na egzaminie. W drugim natomiast student odgrywa rolę nauczyciela wychowania fizycznego, który udziela rad swoim uczniom na temat zachowania dobrej kondycji. Ostatnie zadanie polega na odtworzeniu scenki rodzajowej, w której jedna z osób jest dziennikarzem przeprowadzającym wywiad z ftyzjatrą (specjalistą w leczeniu gruźlicy).

${ }^{14}$ Niektóre z pytań treścią i formą przypominają pytania egzaminacyjne, np. Proszę odpowiedzieć na pytania: czy lekarz powinien informować pacjenta o chorobie nowotworowej?; Prosze odpowiedzieć na pytanie: Na czym polega pierwsza pomoc przy krwotoku, zranieniu, złamaniu itp.?; Proszę rozwinać temat: AIDS w Pana kraju. 
beli), określanie, czy zdanie jest prawdziwe czy fałszywe, wybieranie poprawnej odpowiedzi, udzielanie odpowiedzi na pytania otwarte. Ćwiczenia angażujące inne sprawności to na przykład układanie pytań do nagrania, uzupełnianie tabeli, formularzy takich jak recepta, wywiad lekarski, skierowanie.

Analiza materiału prowadzi do wniosku, iż ćwiczenia zostały opracowane według wytycznych metodyki zadaniowej. Uczący się mają wejść w rolę i wykonać konkretne zadanie, np. zrelacjonować stan zdrowia pacjenta innemu lekarzowi (na podstawie karty chorobowej), przeprowadzić wywiad lekarski z pacjentem, następnie zaproponować badania. W dialogach lekarz - pacjent pojawiały się zadania typu: pocieszenie płaczącego pacjenta, wyjaśnienie wyników badań, informowanie o przebiegu leczenia członków najbliższej rodziny, uspokojenie zdenerwowanej kobiety, u której rozpoczęła się akcja porodowa. Kolejnym zadaniem, z którym musi zmierzyć się student, jest wcielenie się w rolę lekarza-stażysty, który opisuje stan zdrowia pacjentów w trakcie odbywającego się konsylium lekarskiego. Dzięki bogatemu i różnorodnemu inwentarzowi zadań uczący ma szansę w pełni rozwijać kompetencje w zakresie komunikacji ustnej.

4. Witaj w Polsce! Podręcznik do nauki języka polskiego dla studentów medycyny

Podręcznik ten składa się z trzech części: pierwsza jest poświęcona nauce języka ogólnego, druga nauce odmiany specjalistycznej, natomiast trzecia dostarcza podstawowych wiadomości na temat polskich struktur gramatycznych. Oprócz treści czysto teoretycznych znajdują się tam również ćwiczenia gramatyczne. Dodatkiem do podręcznika jest słownik polsko-angielski oraz apendyks obejmujący wybrane epikryzy, przykładowe formularze dokumentacji medycznej oraz przykładowe dialogi, a raczej pytania i sugerowane odpowiedzi, które mogą pojawić się w trakcie badania podmiotowego.

Do podręcznika nie dołączono płyty $\mathrm{CD}$, ale wszystkie nagrania dialogów oraz tekstów narracyjnych znajdują się na stronie internetowej Wydawnictwa Pomorskiego Uniwersytetu Medycznego. Praca z nagraniami polega wyłącznie na odsłuchaniu konkretnego tekstu albo listy słów. Ćwiczenia tego typu mają na celu zapoznanie uczących się z fonetyką i brzmieniem języka, co uznać należy za zaletę. Brakuje jednak ćwiczeń, które wspomagałyby proces rozwijania sprawności rozumienia ze słuch. W części drugiej, poświęconej językowi medycznemu, techniki rozwijające sprawność słuchania są identyczne jak w części pierwszej. Jedynymi technikami wspomagającymi proces nabywania rozumienia tekstu słuchanego są pytania otwarte (jedenaście) oraz ćwiczenia typu prawda/fałsz. Pewne wątpliwości budzi jednak samo formułowanie zdań, zwłaszcza tych, w ćwiczeniach typu prawda/fałsz, por.:

W dwunastnicy pokarm miesza się z sokiem truskawkowym i żółcią. (Nagranie: W dwunastnicy pokarm miesza się z sokiem trzustkowym i żółcią)

Choroby układu krążenia głównie dotyczą płuc. (Nagranie: Choroby układu krążenia głównie dotyczą serca) 
Proces trawienia rozpoczyna się w żołądku (Nagranie: Proces trawienia rozpoczyna się w jamie ustnej).

Podane wyżej przykłady pokazują, że w zadaniach tych weryfikowana jest raczej wiedza przedmiotowa oraz umiejętność słyszenia niż słuchania ze zrozumieniem. Poza tym aby odpowiedzieć na niektóre z pytań, nie trzeba uważnie słuchać ani też dokładnie słyszeć tekstu zadania ${ }^{15}$. Konieczne jest więc wypracowanie takiej konstrukcji zadań, aby student naprawdę musiał się skupić na treści zadania, a nie odwoływał się do swojej wiedzy, która w przypadku zacytowanych powyżej przykładów jest niezwykle pomocna ${ }^{16}$.

W części medycznej podręcznika sprawności mówienia nie poświęca się zbyt wiele miejsca. Najczęściej jest to ćwiczenie typu Practice similar dialogues with your partner. Jeśli podręcznik miał być przeznaczony do sprawnej komunikacji, za dyskusyjne uważam techniki takie, jak Transalte the dialogue into English then listen and practise it with your partner. W tego typu ćwiczeniach sprawdzana jest zdolność poprawnego tłumaczenia na język angielski, a nie umiejętność mówienia. Zastosowane techniki odbiegają więc daleko od głównych założeń oraz koncepcji rozwijania umiejętności sprawnego komunikowania się.

Choć w metodyce nauczania języka polskiego jako obcego pojawiają się głosy przychylne wobec używania języka angielskiego jako języka pośredniego (Ławnicka-Borońska, Kubacka 2016; Ławnicka-Borońska, Rudnik, Wiśniewska 2011), temat ten wymaga szerszych badań i jest zagadnieniem do osobnego omówienia.

5. U lekarza. Stucham i rozumiem. Materiały do nauczania języka polskiego medycznego. Poziom A2-B2

Jest to najnowsza na rynku glottodydaktycznym pozycja wydawnicza poświęcona nauczaniu języka medycznego obcokrajowców. Sam tytuł podręcznika sugeruje, że w opracowaniu największy nacisk będzie kładziony na kształcenie rozumienia ze słuchu. Analiza materiału wykazuje konsekwencję autorów w realizowaniu deklarowanej koncepcji - sprawności słuchania poświęca się w tym podręczniku najwięcej miejsca. Każda $\mathrm{z}$ dwunastu jednostek zawiera segment wprowadzający leksykę wraz z ćwiczeniami rozwijającymi słownictwo i doskonalącymi rozumienie tekstu pisanego. Centralny komponent stanowią ćwiczenia służące rozwijaniu sprawności słuchania. Każdy z rozdziałów zamyka część komunikacyjna. Za ogromny walor podręcznika U lekarza uznać należy ćwiczenia leksykalne, które stanowią wprowadzenie do omawianego tematu. Niemal wszystkie rozdziały rozpoczynają się od prostych ćwiczeń leksykalnych, w których należy połączyć słowa z obrazkami bądź (zdecydowanie rzadziej) z defini-

${ }^{15} \mathrm{~Np}$. Kość udowa to najdluższa i najgrubsza kość w szkielecie człowieka.

${ }^{16}$ Pojawiają się również potknięcia w formułowaniu pytań otwartych, por. 1. Dlaczego pani Maria telefonuje do lekarza?; 2. Jakie objawy ma jej mąż? Ciągi pytań są błędnie skonstruowane, ponieważ kolejne zawierają odpowiedzi na poprzednie. 
cją, wyjaśnieniem. Alternatywą dla takich zadań są techniki polegające na przyporządkowywaniu słownictwa do właściwej kolumny. Tego typu techniki nie tylko pełnią rolę bodźca do rozwijania wszystkich czterech sprawności, ale również stanowią input językowy.

W omawianej pozycji znajdują się klasyczne przykłady ćwiczeń rozwijających sprawność słuchania, które mogą być wykonane w trakcie albo po wysłuchaniu nagrania: uzupełnienie luk w tekście, dopasowywanie obrazków (wymiennie: numerów, osób, tytułów) do nagrań, techniki wielokrotnego wyboru oraz typu prawda/fałsz, układanie fragmentów (albo obrazków) we właściwej kolejności, uzupełnianie tabel (kart pacjenta), diagramów na podstawie wysłuchanej treści. Do ciekawszych (niewystępujących w żadnym innym podręczniku) ćwiczeń należą te, w których trzeba wysłuchać nagrania i podkreślić błędne słowa. Oprócz tego w podręczniku zamieszczone są ćwiczenia wykorzystywane w początkowych etapach nauki, mianowicie podkreślanie słowa, które padło w nagraniu (wersja trudniejsza - notowanie usłyszanych słów). Cechą charakterystyczną zadań w omawianym podręczniku jest ich różny, wzrastający stopień trudności. Do podręcznika dołączona jest płyta CD z 46 nagraniami (dialogi, wypowiedzi narracyjne). W 20\% nagrań pojawiają się zakłócenia w postaci hałasu dobiegającego z korytarza, szumu przejeżdżających samochodów bądź krótkich dźwięków w postaci odgłosu zamykanych drzwi albo zdejmowanego ubrania. $\mathrm{W}$ trzech nagraniach, gdzie odbywa się rozmowa między okulistą a pacjentem, w grupie lekarzy oraz między potencjalnymi pacjentami, usłyszeć można podkład muzyczny. I o ile pojawianie się w tle zakłóceń jest wskazane, o tyle słuszność użycia nagrania muzycznego, które jest tłem rozmowy pacjenta z okulistą, jest nieco dyskusyjna. Mimo że lektorzy dbają o zbliżenie do naturalnego tempa wypowiedzi, trudno nie odnieść wrażenia, że rozmowy są w pewnym stopniu sztuczne. Ponadto głosu użyczają tylko osoby młode, brak ludzi starszych, których ton głosu z pewnością wprowadziłby więcej naturalności i przełamałby panującą w dialogach monotonię.

Pokaźny zbiór zadań oraz ćwiczeń komunikacyjnych dowodzi, iż w podręczniku U lekarza kładzie się szczególny nacisk na kształcenie i rozwijanie sprawności mówienia. Najczęściej jest to przeprowadzenie dialogu (z pacjentem, lekarzem, chorą koleżanką / chorym kolegą). Różnorodność zadań sprawia, że osoba ucząca się ma okazję wcielić się $\mathrm{w}$ różne role ${ }^{17}$. Do instrukcji dołączone są również listy potrzebnych słów (wyrażeń) albo karty pacjenta. Zdecydowaną

${ }^{17}$ Przykładowe zadania: 1. Pani/Pana znajoma dzwoni z problemem. Jej córka od rana źle się czuje - ma stan podgoraczkowy (37,7 stopni), trochę boli ja gardto i głowa. Co Pani/pan może poradzić znajomej? Proszę odegrać dialog z koleżanka/kolega z grupy; 2. Twoja koleżanka/kolega idzie po raz pierwszy na wizytę do laryngologa. Proszę opowiedzieć jej/mu, jak wygląda rutynowe badanie laryngologiczne, o co lekarz może pytać i jakie zalecenia może dać; 3. Proszę wcielić się $w$ rolę laryngologa i powiedzieć, co powinien robić pacjent, który ma zapalenie zatok. Proszę wykorzystać podane wyrażenia i ilustracje. 
mniejszość stanowią zadania, w których osoba ucząca się musi przygotować krótką wypowiedź argumentacyjną ${ }^{18}$. W analizowanym podręczniku dominują wypowiedzi dialogowe i takie też są ćwiczone. Ciekawym rozwiązaniem wydają się ćwiczenia, w których wykorzystywane są fotografie, np. ułożenie fotografii $\mathrm{w}$ poprawnej kolejności, następnie opowiedzenie historii ${ }^{19}$.

\section{PODSUMOWANIE}

Zestawienie deklaracji oraz koncepcji autorów odnoszących się do rozwijania sprawności słuchania i mówienia z rzeczywistą treścią materiałów zawartych w podręcznikach pozwala na sformułowanie kilku wniosków.

Po pierwsze, nie wszystkie podręczniki w pełni realizują deklarowane koncepcje oraz cele metodyczne. Po drugie, techniki rozwijania sprawności słuchania oraz mówienia bazują na osiągnięciach oraz założeniach metodyki nauczania języka ogólnego. Po trzecie, materiały audio są spreparowane oraz wyczyszczone z zakłóceń. O ile na poziomach niższych jest to wręcz wskazane, o tyle poziomy wyższe wymagają nagrań jak najbardziej zbliżonych do autentycznej komunikacji.

W niektórych podręcznikach można zauważyć brak gradacji trudności zarówno tekstów do słuchania, jak i ćwiczeń - są one zdecydowanie za łatwe albo za trudne. Ogromną zaletą nowszych podręczników są ćwiczenia, które sprawdzają nie tylko rozumienie tekstu, ale też jego poprawne słyszenie - są to techniki typu uzupełnianie luk albo podkreślanie niepasujących/pasujących do tekstu słów. Kwestią dyskusyjną jest dobór materiału w takich ćwiczeniach. Istotne jest, aby poprawna odpowiedź nie wynikała z kontekstu. Tworzenie tego typu ćwiczeń nie należy do łatwych, często bowiem brakujące słowo można odgadnąć na podstawie kontekstu.

Techniki rozwijające sprawność mówienia mają na celu nabycie umiejętności zadawania pytań: wywiad z pacjentem, zbieranie historii choroby, pytanie o objawy, rozmowa telefoniczna z pacjentem bądź innym pracownikiem medycznym. Drugą ćwiczoną umiejętnością jest relacjonowanie wydarzeń (przekazywanie informacji o stanie zdrowia bliskim pacjenta bądź członkom personelu medycznego, zespołowi terapeutycznemu). W ostatniej grupie znalazły się następujące funkcje językowe: wyjaśnienie (formułowanie diagnozy i leczenia, informowanie

${ }^{18}$ Przykładowe pytania: Jakie znasz choroby wieku dziecięcego?; Czy ubezpieczenie zdrowotne jest w Polsce obowiazkowe?; Przeciwko jakim chorobom szczepi się dzieci?; Jakie sq objawy cukrzycy; Czy emerytura to zawód?; Gdzie można zarazić się malarią?

${ }^{19}$ Przykładowe polecenia: Na podstawie sekwencji obrazków proszę opisać badanie laryngologiczne z perspektywy lekarza; Na podstawie sekwencji obrazów i podanych stów proszę opisać, co się stało pacjentowi. 
pacjenta, innych lekarzy), wydawanie poleceń, udzielanie rad, definiowanie, opis procesu oraz opis struktury.

Podsumowując powyższe analizy technik doskonalących umiejętności mówienia, należy przed wszystkim zwrócić uwagę na osadzanie uczących się w autentycznej sytuacji komunikacyjnej, realnym kontekście medycznym. Jest to niewątpliwy walor tych ćwiczeń. Najczęściej autorzy sięgają po dialog pacjentlekarz. Zdecydowanie mniej jest rozmów typu: lekarz-lekarz; lekarz-personel medyczny. W starszych pozycjach autorzy chętniej sięgają po bodziec słowny - pojedyncze słowo bądź pytanie, natomiast w nowszych pozycjach można zauważyć liczne ćwiczenia opierające się na bodźcu wizualnym (choć nie brakuje też słownych). Można odnieść wrażenie, że zrezygnowano całkowicie z bodźców dźwiękowych, choć nie oznacza to, że lektorzy w ogóle ich nie wykorzystują ${ }^{20}$.

Autorka niniejszego artykułu ma świadomość ogromnego wysiłku włożonego przez twórców w przygotowanie omawianych podręczników oraz skali trudności, z jaką musieli się zmierzyć. Wynika to z faktu, że metodyka nauczania polskiego języka jako obcego do celów specjalistycznych jest dyscypliną stosunkowo nową. Niemniej jednak wyżej podpisana żywi przekonanie, że poddawanie analizom materiałów, które już powstały, stawianie kolejnych pytań i podejmowanie prób wypracowania nowych rozwiązań jest warunkiem rozwoju glottodydaktyki polonistycznej.

\section{BIBLIOGRAFIA}

Burzyńska-Kamieniecka A., 2015, Umiejętność rozumienia ze słuchu w świetle Europejskiego systemu opisu kształcenia językowego i Standardów wymagań egzaminacyjnych, w: E. Lipińska, A. Seretny (red.), Umiejętność rozumienia i tworzenia tekstów w świetle Standardów wymagań egzaminacyjnych oraz Europejskiego systemu opisu kształcenia językowego, Kraków, s. $39-55$.

Chłopek Z., 2016, Rozwijanie sprawności receptywnych w języku obcym, „Język Obce w Szkole”, nr 1, s. 4-10.

Chłopicka M., Pukas-Palimaka D., 1988, Założenia lingwistyczne i metodyczne drugiej części podręcznika języka medycznego dla studentów polonijnych, „Przegląd Polonijny” z. 2, s. 119-129.

Chłopicka-Wielgos M., Pukas-Palimąka D., 1996, Nauczanie języka specjalistycznego a nie tylko terminologii, „Acta Universitatis Lodziensis. Kształcenie Polonistyczne Cudzoziemców” t. 7/8, B. Ostromęcka-Frączak (red.), s. 69-80.

Danecka-Chwals A., Pukas-Palimąka D., Chłopicka M., 1979, Z zagadnień nauczania odmiany specjalistycznej języków obcych (na przykładzie nauczania języka medycznego studentów polonijnych), „Przegląd Polonijny” V, z. 4, s. 73-82.

${ }^{20}$ Technika ta nie należy do często wykorzystywanych. W przypadku języka medycznego można wykorzystać następujące dźwięki: ambulans na sygnale, pracujący kardiomonitor, ciśnieniomierz, defibrylator. 
Danecka-Chwals A., Pukas-Palimąka D., Chłopicka M., 1981, Założenia metodyczne i lingwistyczne podręcznika języka medycznego dla studentów polonijnych, „Przegląd Polonijny” VII, z. 1, s. 57-67.

ESOKJ - Europejski system opisu ksztatcenia językowego: uczenie sie, nauczanie, ocenianie, 2003, Warszawa.

Filipowicz G., 2016, Stuchać, by mówić lepiej?, „Języki Obce w Szkole”, nr 2, s. 61-65.

Gajewska E., 2011, Techniki nauczania języka obcego, Tarnów.

Gajewska E., Sowa M., 2014, LSP, FOS, Fachsprache... Dydaktyka języków specjalistycznych, Lublin.

Gaszyńska-Magiera M., 2008, Stuchanie - sprawność trudna, zaniedbywana, czy źle uczona? w: E. Lipińska, A. Seretny (red.), Rozwijanie i testowanie biegłości w języku polskim jako obcym, Kraków, s. 29-39.

Gębal P.E., 2019, Dydaktyka języków obcych. Wprowadzenie, Warszawa.

http://www.sjikp.us.edu.pl/pl/biblioteka-lektora/materialy-pomocnicze-rozne-kompetencje/ [04.06.2020].

https://nil.org.pl/dla-lekarzy/mlodzi-lekarze/4282-egzaminy-z-jezyka-polskiego [04.06.2020].

Janowska I., 2019, Wypowiedź ustna $w$ dydaktyce językowej. Na przykładzie języka polskiego jako obcego, Kraków.

Komorowska H., 2009, Metodyka nauczania języków obcych, Warszawa.

Ławnicka-Brońska M., Kubacka K., 2016, Język polski medyczny w wybranych materiałach dydaktycznych ostatniego ćwierćwiecza, „Acta Universitatis Lodziensis. Kształcenie Polonistyczne Cudzoziemców" t. 23, G. Zarzycka, M. Biernacka (red.), s. 215-234. http://dx.doi. org/10.18778/0860-6587.23.17

Ławicka-Borońska M., Rudnik W.J., Wiśniewska J., 2011, Kurs języka polskiego jako obcego dla studentów medycyny, w: K. Pluskota, K. Taczyńska (red.), Nowe perspektywy w nauczaniu języka polskiego jako obcego II, Toruń, s. 321-332.

Miodunka W.T., 2016, Glottodydaktyka polonistyczna. Pochodzenie - stan obecny - perspektywy, Kraków.

Oczko P., w druku, Koncepcje rozwijania sprawności językowych w nauczaniu polskiego języka medycznego, w: Komunikacja specjalistyczna w edukacji, translatoryce i językoznawstwie 4, Rzeszów.

Seretny A., Lipińska E., 2005, ABC metodyki nauczania języka polskiego jako obcego, Kraków.

Swoboda-Rydz U., 2018, Czy możliwe jest zanurzenie w języku specjalistycznym w: P. Potasińska, M. Stasieczek-Górna (red.), Wyzwania glottodydaktyki polonistycznej. „Życie zaczyna się po sześćdziesiątce”, Warszawa, s. 203-2013.

Taczyńska K., 2011, Językowe dolegliwości lekarzy obcokrajowców, w: K. Pluskota, K. Taczyńska (red.), Nowe perspektywy w nauczaniu języka polskiego jako obcego II, Toruń, s. 293-302.

Zawadzka E., 2004, Nauczyciele języków obcych w dobie przemian, Kraków.

\section{Wykaz analizowanych materiałów}

Bilnicka B., 2018, Witaj w Polsce! Podręcznik do nauki języka polskiego dla studentów medycyny, Szczecin.

Chłopicka-Wielgos M., Pukas-Palimąka D., Turek-Fornelska K., 2015, Co Panu dolega? Podręcznik z płyta CD do nauczania cudzoziemców języka polskiego na studiach medycznych. Poziom $B 2 / C$, Kraków.

Jurek T., 2007, Proszę mi powiedzieć, co się stało? Podręcznik języka polskiego dla studentów medycyny, Poznań.

Lechowicz J., Podsiadły J., 1998, Chcę studiować medycynę. Język polski dla cudzoziemców - kandydatów na studia medyczne, Łódź.

Rogala D., Terka B., Burzyńska M., Gruchała W., Rodzińska W., Wawrzeń M., 2019, U lekarza. Stucham i rozumiem! Materiały do nauczania języka polskiego medycznego. Poziom A2-B2, Kraków. 


\section{Inne podręczniki do nauczania języka medycznego}

Bilnicka B., 2003, Język polski dla cudzoziemców, Szczecin.

Danecka-Chwals A., Chłopicka M., Pukas-Palimąka D., 1986, O człowieku po polsku. Podręcznik języka medycznego dla obcokrajowców, Kraków.

Gałat E., 2018, Anatomia - język specjalistyczny. Skrypt dla obcokrajowców na poziomie A2+/B, Kraków.

Janowska M., Sikorska Ś., 2007a, Ja też chcę mówić po polsku, Warszawa.

Janowska M., Sikorska Ś., 2007b, Proszę oddychać. Materiały do nauczania medycznego języka polskiego. Część I i II, Warszawa.

Janowska M., Sikorska Ś., 2015, Proszę oddychać. Materiały do nauczania medycznego języka polskiego. Część III, Warszawa.

Ławnicka-Borońska M., 2013, Język polski w medycynie. A Guide to Polish in Medical Practice, Warszawa.

Swoboda-Rydz U., 2016, Język polski dla stomatologów, Warszawa.

\section{Paulina Oczko}

\section{TECHNIQUES FOR DEVELOPING LISTENING AND SPEAKING SKILLS IN POLISH MEDICAL LANGUAGE TEXTBOOKS}

Keywords: specialist language, Polish medical language, teaching materials, language skills, techniques to develop listening and speaking skills

Abstract. The article is a voice in the discussion on methods of developing listening and speaking skills in teaching Polish medical language. The reason for writing the text were the conclusions from the analysis of the concept of developing language skills presented in (Polish) medical language textbooks. The first part of the text presents the work done so far on textbooks and aids for teaching Polish medical language. It also describes the commonly accepted methods of teaching Polish general language and, for specialist purposes, techniques for developing listening and speaking skills. Part II verifies the declarations and concepts of the authors with the actual state of the materials contained in the textbooks' introductions. The author also discussed the techniques of acquiring and developing listening and speaking skills in medical language textbooks. 